\title{
LIX. A note on the electromotive forces of gold and of platinum cells
}

\section{E. F. Herroun}

To cite this article: E. F. Herroun (1892) LIX. A note on the electromotive forces of gold and of platinum cells, Philosophical Magazine Series 5, 33:205, 516-520, DOI: 10.1080/14786449208620292

To link to this article: http://dx.doi.org/10.1080/14786449208620292

曲 Published online: 08 May 2009.

Submit your article to this journal $[\pi$

Џ Article views: 2

Q View related articles $\asymp$ 
spectrum of sodium, and that the same relation prevails between the two series of triple lines in the spectra of $\mathrm{Zn}, \mathrm{Cd}$, and $\mathrm{Hg}$. 'This is suggested by the circumstance that the line which we now know to be the first term of Series $S$ stands in a position in all these spectra which appears to be related in the same way to the positions in them of the lines of Series D. But what the connexion is we do not yet know.

\section{Description of the Diagrams.}

A sketch on a very small scale of the primary curves of the three sodium series is given in Plate VII. fig. 4, and a sketch of their derived curves is given in fig. 5. In both these figures, as in the diagrams of the corresponding hydrogen curves in Plate VI., the horizontal lines represent the oscillationfrequencies of the successive lines of each series, when measured from the vertical line to the curve belonging to that series. A small circle is placed round those dots that correspond to lines that have not yet been observed, and the cross on the upper line between -500 and -600 indicates the distance to which Professor Hartley has succeeded in photographing in the ultra-violet.

To judge what the approximation is that has been obtained, imagine each of the diagrams enlarged, until the vertical line becomes ten metres long. Each of the diagrams would then occupy the side of a large house. Even on this immense scale the greatest deviation of the observed ends of the horizontal lines from the eurve would be less than six millimetres in the case of Series $\mathrm{S}$, would be under three millimetres in Series $P$, and would be only a fraction of a millimetre in Series D. Although these deviations are very small, modern spectroscopic work is carried out with such accuracy that they may not be attributed to errors of observation, and, accordingly, we are justified in drawing the first and second of the inferences on p. 514.

LIX. A Note on the Electromotive Forces of Gold and of Platinum Cells. $B y$ E. F. Herroun, Professor of Natural Philosophy in Queen's College, London*.

$\mathrm{T}$ nearly all modern text-books of Physics the metal pla1 tinum is placed after gold in Volta's Electropositive Series. This no doubt is partly owing to the well-known fact that gold is attacked by chlorine or nitrohydrochloric acid more readily than platinum, and it might therefore be

* Communicated by the Physical Society: read March 25, 1892. 
reasonably supposed that gold evolves more heat in the formation of its chloride than does platinum. On referring to the values for the heats of formation of the chlorides of these two metals, as given by Julius Thomsen *, one finds, however, that the heat attending the formation of auric chloride is, per equivalent, only about half as great as that in the case of platinic chloride.

Assuming that the voltaic constants of metals are deducible from the thermochemical values of their compounds, the above facts would compel us to regard gold as more negative than platinum, at least when immersed in chloride solutions. (The same observations would also apply if oxygen were the attacking medium, as Thomsen gives the heat of formation of platinic hydrate as a considerable positive number, while that of auric hydrate is a large negative quantity.)

It was, therefore, an interesting point to determine how far the actual electromotive forces obtained with gold and with platinum agreed with these conclusions, and I endeavoured to find records of the electromotive forces of cells in which these metals are immersed in solutions of their chlorides opposed to some other metal in a solution of its corresponding salt. While there are many references to the E.M.F.'s set up in single fluid cells in which platinum is one of the metals used, the references to gold are scanty, and even with platinum I have only succeeded in finding one recorded measurement in which the platinum was immersed in a solution of its own salt. This was a measurement made by Wheatstone $\dagger$, in which liquid zine amalgam was opposed to platinum in a solution of platinic chloride. $\mathrm{He}$ found in measuring the F.M.F. of this cell that it required 40 turns of his rheostat, as compared with 30 turns required for a form of Daniell cell. Now, assuming his Daniell cell to have had an E.M.F. of 1.09 volt, the value in volts for the zinc amalgam, platinumplatinic chloride cell would be $1 \cdot 453$.

In a list of the potential differences between different metals and graphite simply immersed in water, Götz and Kurz $\ddagger$ give the values 0.48 volt for gold and 0.37 volt for platinum, the value for zinc and graphite being 1.37 volt. This would make platinum more electronegative than gold by 0.11 volt; but these values cannot be accepted as in any degree expressing the actual electromotive forces concerned.

Exner and Tuma $\S$, on the other hand, taking carbon $=0$,

* Thermochemische Untersuchungen, iii. pp. 412 \& 430.

+ Wheatstone's Scientific Papers, p. 115.

$\mp$ Electrotechnie Zeit. ii. p. 30.

Wien. Ber. xevii. p. 917 . 
give $\mathrm{Pt}=0.05, \mathrm{Au}=-0.05$, which appear to be much more probable values, and make gold, as its thermochemical data require, negative as regards platinum.

Under these circumstances it appeared worth while measuring the actual E.M.F. set up between zine and gold, and zinc and platinum, in solutions of their own chlorides of equal molecular strength.

\section{Zino-Platinum Cell.}

The heat of formation of $\mathrm{PtCl}_{4}$ is apparently unknown, but as it appears to be impossible to prepare a neutral solution of that salt, compounds such as $\mathrm{PtCl}_{4}, 2 \mathrm{HCl}$ or $\mathrm{PtCl}_{4}, 2 \mathrm{NaCl}$ must be substituted, and their heats of formation are given by Thomsen. I selected the latter salt on account of its freedom from acid, and prepared a neutral solution having the strength of $\cdot 25\left(\mathrm{PtCl}_{4} 2 \mathrm{NaCl}\right) 100 \mathrm{H}_{2} \mathrm{O}$, which therefore contained about $2 \cdot 75$ grams of $\mathrm{Pt}$ in 100 cub. centim. of solution.

Thomsen gives for $\left[\mathrm{Pt}, \mathrm{Cl}_{4}, 2 \mathrm{NaCl}\right.$, aq] the value 73720 $+8540=82,260$ calories; and for $\left[\mathrm{Zn}, \mathrm{Cl}_{2}, \mathrm{aq}\right]$ the value 112,840 calories. These numbers would give as the heat of replacement of one equivalent of platinum by zinc the nett heat evolution of 35,855 , which is equivalent to a theoretical E.M.F. of 1.548 volt.

A cell was set up consisting of an amalgamated pure zinc rod immersed in a solution of $\cdot 25 \mathrm{ZnCl}_{2} 100 \mathrm{H}_{2} \mathrm{O}$, opposed to a ciean platinum plate immersed in the solution of sodio platinic chloride above described. The two solutions were separated both in this and other experiments by an ordinary porous earthenware pot, and the E.M.F. was measured by balancing it against a difference of potential by Poggendorff's method.

The standards taken were a Latimer-Clark cell, which was assumed to have an E.M.F. of 1.435 volt at $15^{\circ} \mathrm{C}$, and a chloride of silver battery (modified De-la-Rue cell), which by comparison with the Clark cell was found to have an E.M.F. of 1.045 volt. I find this cell more convenient in using Poggendorff's, or any similar method, as its E.M.F is not appreciably disturbed by its sending a small current, or by shaking, and it has a smaller temperature-coefficient than the Clark cell. The temperature of all the cells used in these experiments only varied between the narrow limits of from $12^{\circ}$ to $15^{\circ} \mathrm{C}$.

In one experiment the zinc-platinum cell, when first set up, gave an E.M.F. of 1.647 volt. It was then allowed to send a current through a low external resistance for five minutes, and after further resting for five minutes its E.M.F. was again measured, when it was found to have dropped to 1.473 volt. 
After a further rest of about ten minutes it recovered to 1.507 volt, at which value it remained tolerably constant. During the passage of the current from the cell the platinum plate became covered with a black deposit of finely divided platinum, and I thought it not improbable that this alteration of the surface might be the cause of the marked falling off in E.M.F.; but on removing the solution surrounding the platinum plate and replacing it with fresh, the E.M.F. regained its initial high value although the surface of the plate had not been disturbed. It appeared from this that the high initial value was probably due to oxygen dissolved in the liquid, which the platinum would be very apt to occlude superficially, and which would account for the uncertain values of the E.M.F.

Whatever may be the cause, this variability renders the measurement of the E.M.F. of this form of cell very difficult.

In other experiments values as high as 1.7 volt were obtained on first setting up the cell, which, after sending a current and resting, fell to the tolerably stable value of about 1.525 .

Maximum E.M.F. $=1.70$ volt.
Minimum,$\quad \begin{aligned} & =1.473, \\ & \text { Average },\end{aligned} \quad 1.525$,

The average value $(1.525)$ is seen to be slightly lower than the E.M.F. calculated from the thermochemical equation $(1.548)$; but the difference is small ( 023 volt), and is well within the limits of experimental error with such a variable cell. There is therefore no reason to assume that its actual E.M.F. departs from the theoretical value.

\section{Zinc-Gold Cell.}

The heat of formation of $\left[\mathrm{Au}, \mathrm{Cl}_{3}\right.$, aq] is given by Thomsen as 27,270 calories, and that of $\left[\mathrm{Zn}, \mathrm{Cl}_{2}, \mathrm{aq}\right]$ being 112,840 , the difference per equivalent gives $2 \cdot 044$ volts as the theoretical E.M.F. of zinc, displacing gold from weak solutions of its chloride.

A cell consisting of an amalgamated zinc rod immersed in a solution of zinc chloride having the strength of $\cdot 25 \mathrm{ZnCl}_{2} 100 \mathrm{H}_{2} \mathrm{O}$ opposed to a plate of gold in a solution of auric chloride of equal molecular strength, was set up and its E.M.F. immediately measured. It was found to give an E.M.F. of 1.855 volt, and after actual short-circuiting for five minutes it had only fallen to $1 \cdot 834$. These values were in fact the extreme limits of the variations that I have observed on repeating the experiment, and the constancy of this cell 
contrasts in a striking manner with the variability of the platinum cells.

$$
\begin{aligned}
\text { Maximum E.M.F. } & =1.855 \text { volt. } \\
\text { Minimum }, & =1.834, \\
\text { Mean } \quad & =1.844,
\end{aligned}
$$

Assuming the thermal values for gold to be accurate, the actual E.M.F. thus measured is seen to be $\cdot 2$ volt below the calculated value; or, adopting the convention suggested by Messrs. Wright and Thompson, -0.2 volt is the thermovoltaic constant for gold in dilute neutral solutions of its chloride.

When a platinum plate was substituted for the gold plate and immersed in the gold-chloride solution, the E.M.F. of the cell thus formed was found to be 1.782 volt, $i$. e. less than the gold-gold chloride, but greater than the platinum-platinic chloride cell given above.

From the thermochemical values one might conclude that platinum would be capable of replacing gold from gold chloride; but, so far as my experiments have gone, I have not found this to be the case, nor on the other hand is gold able to replace platinum from platinic chloride, which, of course, is not to be expected.

When a plate of gold and another of platinum are immersed together in pure water or in dilute hydrochloric acid, the gold acquires slightly the higher potential. If strong hydrochloric acid be substituted for the dilute, the direction of the difference of potential becomes doubtful, and on the addition of nitric acid to the strong hydrochloric, so as to form aqua regia, the platinum acquires distinctly the higher potential, and if the outside circuit be closed on a galvanometer, a very decided current flows from the gold to the platinum through the cell ( $c f$. Ganot's Physics, article on "Electromotive Series").

Why the nascent chlorine combines readily with the gold where it evolves but little heat and slowly and reluctantly with the platinum, in which reaction much more heat is disengaged, is a problem which at present appears to admit of no satisfactory solution. 